\title{
Kompetensi Pembimbing dalam Sistem Latihan Kemahiran Dua Hala: Satu Sorotan Literatur
}

\author{
Nasyitah Nasir a, Siti Balkhis Adama, Nur Najihah Roslia, Mai Shihah Abdullahº, Mohamed Nor Azhari Azmana*
}

aJabatan Teknologi Kejuruteraan, Fakulti Pendidikan Teknikal dan Vokasional, Universiti Pendidikan Sultan Idris, 35900 Tanjung Malim, Perak, Malaysia

bJabatan Biologi, Fakulti Sains dan Matematik, Universiti Pendidikan Sultan Idris, 35900 Tanjong Malim, Perak, Malaysia

*Corresponding author: mnazhari@fptv.upsi.edu.my

\begin{abstract}
National Dual Training System (NDTS) implementation in Malaysia was designed to produce highly skilled and knowledgeable K-workers, equipped with the social skills and learning methodologies. Research used documentation as data collection methods and data was analysed using historical, inductive and deductive reasoning method. The Ninth Malaysia Plan has stated four challenges which need to be addressed in developing the Technical and Vocational Education Training (TVET) sector. One of the issues is competency gaps among instructors. Based on the issue, the research objective is to identify the competency levels among instructors of NDTS. There are three aspects need to be applied by instructors during their teaching and learning session which include (1) technical skills, (2) knowledge, and (3) behaviour. This research is further into assessment as the platform to measure competency quality among the instructors of NDTS. The result showed that, the assessment based competency is able to improve the competency levels among the instructors of NDTS.
\end{abstract}

Keywords: Knowledge, K-workers; social skills; technical skills; competency; dual training

\begin{abstract}
Abstrak
Pelaksanaan Sistem Latihan Dual Nasional (SLDN) di Malaysia adalah bertujuan untuk melahirkan K-pekerja yang berkemahiran tinggi dan berpengetahuan, lengkap dengan nilai kemahiran sosial dan metodologi pembelajaran. Kajian ini menggunakan metodologi pengumpulan data secara dokumentasi dan data dianalisis secara historis, induktif dan deduktif. Rancangan Malaysia Kesembilan menyatakan empat cabaran yang perlu ditadbir urus dalam usaha membangunkan sektor Latihan Pendidikan Teknikal dan Vokasional (TVET). Salah satu isu adalah jurang kompetensi dalam kalangan pembimbing. Berdasarkan isu ini, objektif kajian adalah untuk mengenal pasti tahap kompetensi dalam kalangan pembimbing SLDN. Terdapat tiga aspek yang perlu diaplikasikan oleh pembimbing semasa sesi pengajaran dan pembelajaran termasuklah (1) kemahiran teknikal (2) pengetahuan dan (3) tingkah laku. Seterusnya, kajian lanjut dilakukan terhadap aspek penilaian, di mana ia menjadi landasan bagi mengukur kualiti kompetensi yang dimiliki pembimbing SLDN. Keputusan kajian mendapati bahawa, penilaian berasaskan kompetensi ini mampu meningkatkan tahap kompetensi dalam kalangan pembimbing SLDN.
\end{abstract}

Kata kunci: pengetahuan, K-pekerja; kemahiran sosial; kemahiran teknikal; kompentensi, latihan dual

(C) 2017 Penerbit UTM Press. All rights reserved

\subsection{PENGENALAN}

Bermula tahun 2005, Jabatan Pembagunan Kemahiran, Kementerian Sumber Manusia telah memperkenalkan Sistem Latihan Dual Nasional (SLDN). Berdasarkan kajian Othman et al. (2011), sistem ini telah diperkenalkan oleh Kabinet Malaysia pada 19 Mei 2004 bermula dengan empat set kemahiran iaitu alat pembuatan (alat dan acuan), proses kawalan automatik, mekanik automotif dan operasi kilang. Menurut Hasmori et al. (2011), sistem ini terhasil daripada perjanjian usaha sama di antara negara Jerman dan Malaysia pada tahun 1996 dan antara inisiatif sistem ini dilaksanakan ialah mampu untuk menghasilkan tenaga kerja yang berketerampilan, mempunyai pengetahuan yang pelbagai, minat untuk terus belajar bagi mempertingkatkan kemampuan untuk mendapat dan menggunakan pengetahuan yang lain khususnya dalam teknologi maklumat. Menurut Deros et al. (2012), tujuan utama sistem ini dilaksanakan ialah untuk melahirkan tenaga mahir K-pekerja bagi memenuhi hasrat negara dalam membangunkan ekonomi.

Menurut Salleh (2013), Malaysia menjalankan Sistem Latihan Dual Nasional (SLDN) ini di dua tempat iaitu di industri yang meliputi $70 \%$ hingga $80 \%$ dan di institusi latihan yang meliputi $20 \%$ hingga 30\%. Pendekatan latihan SLDN ditentukan oleh industri bersama-sama dengan pihak institusi sama ada menggunakan pendekatan day release atau block release mengikut kesesuaian industri tersebut. Apabila menggunakan pendekatan day release, pelatih menjalani latihan selama 4 hingga 5 hari di industri dan 1 hingga 2 hari di institusi latihan. Pendekatan block release pula berlaku apabila pelatih menjalani latihan di industri selama 4 hingga 5 bulan serta latihan selama 1 hingga 2 bulan di institusi latihan. Pelatih yang berjaya menamatkan kursus selama dua tahun yang terbahagi kepada empat semester dianugerahkan sijil K-pekerja yang mana sijil ini setaraf dengan Sijil Kemahiran Malaysia (SKM) tahap 3 yang diperakui 
oleh majlis latihan vokasional kebangsaan (MLVK) dan industri yang berkaitan.

Manakala di Switzerland, sistem dual dijalankan dalam dua tahap berasingan dan setiap satunya mempunyai pensijilan yang tersendiri: pelatih menjalani latihan di peringkat rendah (kurang permintaan dalam pasaran), masa pengajian adalah 2 tahun dan kelayakan bekerja untuk jawatan peringkat bawah. Contohnya, menerima Switzerland's federal vocational certificate (EBA). Pelatih yang menjalani latihan kemahiran selama tiga atau empat tahun lebih mendapat permintaan yang tinggi dalam industri untuk menyandang jawatan yang lebih tinggi. Contohnya, menerima Switzerland's federal vocational certificate of proficiency (EFZ) (Euler, 2013).

Sistem dual di Netherlands pula menawarkan empat tahap berbeza dalam latihan kemahiran, yang mana ianya boleh terlaksana secara dual atau berorentasikan sekolah: latihan sebagai pembantu (tahap 1, maksimum setahun), latihan asas vokasional (tahap 2, 2-3 tahun), latihan kemahiran vokasional (tahap 3, 3-4 tahun), latihan pertengahan pengurusan atau pakar (tahap 4, 3-4 tahun). Latihan secara dual mendapat terlalu ramai penyertaan pada peringkat rendah dan terlalu sedikit penyertaannya pada peringkat tinggi. Dalam tempoh tersebut dengan mengambil kira kesemua tahap, terdapat 700 jenis pensijilan yang berasingan dianugerahkan di Netherlands. Kebanyakan kursus latihan dipecahkan kepada kelayakan separa atau disebut sebagai modul. Pelatih menerima sebuah dokumen yang mengesahkan mereka berjaya menyiapkan setiap kelayakan separa atau modul; setelah berjaya menyelesaikan semua latihan dalam kelayakan separa atau modul, barulah pelatih dianugerahkan sijil. Selain itu, pengajian bukanlah berorentasikan peperiksaan akhir sebaliknya, beberapa peperiksaan dilaksanakan di syarikat, tetapi kekerapanyang lebih banyak dilaksanakan di institut pengajian oleh tenaga pengajar yakni peperiksaan yang berdasarkan latihan amali yang telah dijalani (Euler, 2013).

Berbeza dengan amalan di England, pelaksanaan sistem dual menawarkan tiga tahap pengajian. Tahap latihan peralihan, tempoh 9-12 bulan; tahap latihan pemajuan, tempoh 1-2 tahun; tahap latihan tinggi, tempoh 3-4 tahun (Euler, 2013).

Tidak dapat dinafi lagi, latihan kemahiran adalah salah satu elemen yang berkait rapat dan relevan dengan kehendak Pendidikan Teknikal danVokasional (TVET). Menurut Alwi (2006), latihan kemahiran telah menjadi komponen yang semakin dikenali dalam sistem latihan kemahiran di Malaysia. Isu utama dalam senario TVET Malaysia adalah keberkesanan pembelajaran terutamanya programprogram latihan kemahiran untuk memenuhi keperluan industri. Sistem ini dilaksanakan bagi menyediakan tenaga mahir negara, K-pekerja yang kompeten dalam bidang teknikal, metodologi pembelajaran dan sosial melalui satu kaedah latihan yang komprehensif dan terkini selari dengan keperluan industri.

Pemantapan sistem ini untuk dilaksanakan dalam sistem pendidikan dan latihan ialah melalui RMKe-8, yakni bertujuan mengeluarkan tenaga kerja yang mempunyai pelbagai kemahiran, berpengetahuan serta serba boleh, bersedia untuk belajar secara berterusan, memiliki ciri-ciri usahawan teknologi serta berkebolehan untuk mendapat dan menggunakan ilmu pengetahuan terutamanya dalam teknologi moden yang digunakan oleh industri masa kini dan terus dipacu dalam menghasilkan tenaga kerja yang mempunyai banyak kemahiran, berpengetahuan serta sanggup untuk terus belajar secara berterusan pada masa hadapan. SLDN dilihat sebagai satu sistem latihan yang amat berpotensi dalam menghasilkan tenaga kerja berkemahiran yang diperlukan oleh negara dalam memacu ekonominya kearah pencapaian status negara maju menjelang tahun 2020.

Sememangnya, SLDN memainkan peranan penting dalam melahirkan pelatih-pelatih yang berkompetensi tinggi selaras dengan sasaran rancangan Malaysia kesembilan. Walau bagaimanapun, terdapat beberapa kekangan dalam pelaksanaan SLDN, antaranya adalah masalah jurang kompetensi dalam kalangan pembimbing seperti yang telah disebut dalam isu dan cabaran TVET dalam RMKe-9. BMZ (2011), mendefinisikan perkataan kompeten sebagai keupayaan seseorang untuk memilih dan menggunakan gabungan bersepadu pengetahuan, kemahiran dan sikap untuk merealisasikan sesuatu tugas atau kerja dalam bidang tertentu. UNESCO-UNEVOC (2012), pula memberi takrifan kompetensi merangkumi kompetensi standard. Kompetensi adalah sebagai keupayaan sesorang individu, yang mana adalah untuk digunakan, diaplikasikan dalam membimbing kumpulan pelatih berkaitan dengan pengetahuan, kemahiran dan sikap yang diperlukan untuk melaksanakan tugas-tugas dengan jayanya. Ia boleh diukur dengan standard yang diperlukan dalam penilaian prestasi di tempat kerja. Sesungguhnya, kompetensi ini memberi kesan kepada tanggungjawab kerja individu dan prestasi di tempat kerja dan biasanya terbahagi kepada dua kategori, iaitu teknikal dan tingkah laku. Sementara itu, IBSA (2012), mendefinisikan kompetensi standard sebagai penentuan keperluan yang diperlukan dalam memastikan prestasi kerja yang kompeten dalam apa jua keadaan. Secara umumnya, ia digunakan sebagai penanda aras dalam melaksanakan penilaian dalam Pendidikan Vokasional dan sektor Latihan (VET).

Menurut Daud (2003), kompetensi bermakna "competence, proficiency, skillful and skill". Kompetensi ditakrifkan sebagai gabungan aspek pengetahuan, kemahiran dan ciri-ciri peribadi yang perlu dimiliki serta diamalkan bagi melaksanakan sesuatu pekerjaan atau jawatan. Prinsip asas model kompetensi ialah prestasi seseorang pegawai perkhidmatan awam akan meningkat sekiranya beliau mempunyai semua kompetensi yang diperlukan bagi menjalankan tugas dan tanggungjawab jawatan yang disandangnya. Sebagai contoh, pengkhususan dalam sesuatu bidang dan kekerapan melaksanakan sesuatu tugas yang akan membolehkan pegawai melaksanakan tugasnya dengan berkesan dan cemerlang. Dharma (2003), mentakrifkan kompetensi sebagai kemampuan atau kecekapan yang ditunjukkan oleh seseorang ketika melakukan sesuatu. Secara umumnya, kompetensi merupakan keupayaan seseorang untuk mencapai matlamat interaktif, dalam konteks sosial yang khusus, dengan menggunakan cara yang diterima dan dapat memberikan hasil yang positif. Kompetensi dalam pandangan pengkaji pula, merujuk kepada pengetahuan, kemahiran, dan ciri-ciri peribadi atau personality traits yang perlu bagi melaksanakan sesuatu tugas atau tanggungjawab.

Atikah (2015), dalam kajiannya menyebut, masalah yang telah dikenal pasti yang menyebabkan pembimbing tidak kompeten dalam SLDN ialah pendedahan industri yang minimum dan kekurangan tahap kemahiran dari pembimbing itu sendiri. Oleh sebab itu, pembimbing yang tidak kompeten dalam sistem ini akan melahirkan graduan yang tidak kompeten dan kurang berkemahiran sebagaimana yang dikehendaki oleh industri dan teknologi pada masa kini. Pembimbing juga kurang ilmu pengetahuan untuk mengenal pasti dan membina bakat pelatih. Hal ini menyebabkan pelatih tidak tahu untuk mengaplikasikan kekuatan mereka dalam melaksanakan kemahiran baharu yang diperoleh oleh mereka. Pembimbing yang kurang berpengetahuan juga akan menyebabkan pelatih kurang bermotivasi dan kurang mengambil bahagian dalam institusi. Azlan (2011), menyatakan bahawa sikap negatif pembimbing seperti tidak mengambil berat tentang tanggungjawab membimbing pelatih dan bersikap sambil lewa dalam menjalankan tugas mereka sebagai seorang pembimbing juga menyebabkan pelatih tidak mempunyai kemahiran yang cekap dan mereka tidak mengetahui cara untuk mengaplikasikan apa yang telah dipelajari ketika berada dalam industri yang mereka akan ceburi nanti.

Jelas di sini kompetensi pembimbing adalah cabaran terbesar dalam pelaksanaan SLDN yang mana bertujuan melahirkan tenaga kerja yang berketerampilan, mempunyai pengetahuan yang pelbagai, minat untuk terus belajar bagi mempertingkatkan kemampuan untuk mendapat dan menggunakan pengetahuan yang lain khususnya dalam teknologi maklumat, kearah pencapaian status negara maju 
menjelang tahun 2020. Pihak yang terlibat hendaklah bersifat tidak berdiam diri dalam menghapus jurang kompetensi dalam kalangan pembimbing SLDN. Tujuan kajian ini dijalankan adalah untuk menganalisis dapatan kajian terdahulu untuk mengenal pasti tahap kompetensi pembimbing dalam SLDN dari segi pengetahuan, kemahiran, dan sikap serta bagaimana tahap kompetensi minimum dapat dikukuhkan menjadi tahap kompetensi standard, melalui pelaksanaan penilaian, bagi memenuhi hasrat negara dalam membangunkan ekonomi.

\subsection{SOROTAN LITERATUR}

\section{Konsep Kompetensi}

Berdasarkan kajian-kajian terdahulu yang terdapat pada Jadual 1, satu analisis dokumentasi yang berkaitan dengan tahap kompetensi telah dijalankan. Carian yang telah dijalankan memperoleh sebanyak 10 kajian yang mana boleh digunakan untuk membandingkan dengan teoritikal yang menyokong kepada faktor-faktor yang mempengaruhi tahap kompetensi pembimbing.

Gordon (1998), dalam kajiannya mengemukakan beberapa dimensi yang terkandung dalam konsep kompetensi adalah sebagai berikut: (1) pemahaman, iaitu kedalaman kognitif yang dimiliki oleh seseorang, (2) kemahiran iaitu keterampilan atau bakat yang dimiliki oleh individu untuk melakukan pekerjaan yang diberi, (3) pengetahuan iaitu kesedaran dalam bidang kognitif, yang bermaksud mengetahui apa yang harus dilakukan, (4) minat, iaitu kecenderungan seseorang yang tinggi terhadap sesuatu perkara atau bidang, (5) sikap iaitu reaksi seseorang terhadap rangsangan yang datang dipengaruhi faktor dari luar, dan (6) nilai iaitu teladan dan contoh peribadi yang ditunjukkan dalam melaksanakan tugas.

Jadual 1 Perbandingan kajian lepas

\begin{tabular}{|c|c|c|c|c|}
\hline Tajuk & 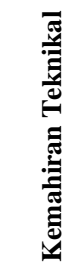 & 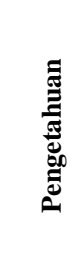 & 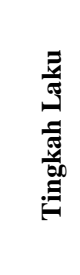 & 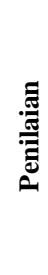 \\
\hline $\begin{array}{l}\text { The Emerging Roles of Coaches in the Malaysian Dual Training System (Ahmad Othman et al., } \\
\text { 2011). }\end{array}$ & $\sqrt{f}$ & $\sqrt{ }$ & $\mathbb{v}^{\prime}$ & \\
\hline $\begin{array}{l}\text { The Development Of a New Malaysian Skills Qualification Framework (MSQF) in the Context } \\
\text { of National Dual Training System (NDTS) (Aruna Ismail, 2013). }\end{array}$ & $\sqrt{t}$ & $\sqrt{ }$ & $\sqrt{ }$ & $\sqrt{8}$ \\
\hline $\begin{array}{l}\text { Competency Based Training: Quality Delivery for Technical and Vocational Education and } \\
\text { Training (TVET) Institutions (Caroline Abba Anane, 2013). }\end{array}$ & $\mathbb{b}^{\prime}$ & $\sqrt{t}$ & $\mathbb{b}^{\prime}$ & $\sqrt{ }$ \\
\hline $\begin{array}{l}\text { Transferable skills education in Technical and Vocational Education and Training (TVET) in the } \\
\text { Republic of Korea (Misung Jin, 2014). }\end{array}$ & $\mathbb{b}^{\prime}$ & $\mathbb{V}^{7}$ & $\mathbb{V}^{\prime}$ & $\sqrt{f}$ \\
\hline $\begin{array}{l}\text { Implementation of National Dual Training System (NTDS) on Producing K-Workers in } \\
\text { Malaysia (Aruna Ismail et al., 2014). }\end{array}$ & $\mathbb{V}^{\prime}$ & $\sqrt{ }$ & $\sqrt{ }$ & \\
\hline $\begin{array}{l}\text { E-Portfolio Indicator for Competency Assessment and Virtual Learning in Malaysia Skills } \\
\text { Certification (Bekeri Rahim, 2015). }\end{array}$ & $\mathbb{v}^{\prime}$ & & & $\sqrt{\prime}$ \\
\hline $\begin{array}{l}\text { Developing The Knowledge-Based Human Resources that Support The Implementation of the } \\
\text { National Dual Training System (NDTS): Evaluation of TVET Teacher's Competency at Mara } \\
\text { Training Institutions Developing The Knowledge-Based Human Resources that Support the } \\
\text { Implementation of The National Dual Training System (NDTS): Evaluation of TVET Teacher's } \\
\text { Competency at Mara Training Institutions (Mahazani Ali, 2015). }\end{array}$ & $\sqrt{ }$ & $\sqrt{ }$ & $\sqrt{ }$ & \\
\hline $\begin{array}{l}\text { Penerapan Nilai-Nilai Murni dalam Proses Pengajaran dan Pembelajaran ke Arah Pembentukan } \\
\text { Sahsiah Pelajar di Kolej Kemahiran Tinggi Mara (Norazri Zaidin, 2015). }\end{array}$ & & & $\sqrt{ }$ & \\
\hline $\begin{array}{l}\text { Kompetensi Pembimbing Syarikat Bertauliah Sistem Latihan Dual Nasional (SLDN) (Atikah } \\
\text { Jizat, 2015). }\end{array}$ & $\sqrt{ }$ & $\sqrt{ }$ & $\sqrt{ }$ & \\
\hline $\begin{array}{l}\text { Enhancing Technical and Vocational Education and Training (TVET) in Nigeria for Sustainable } \\
\text { Development: Competency-Based Training (CBT) Approach (Okoye Michael } \text { et. al., 2015). }\end{array}$ & $\mathbb{b}^{\prime}$ & $\sqrt{ }$ & & $\sqrt{ }$ \\
\hline
\end{tabular}

Walau bagaimanapun, menurut beberapa pengkaji lain, tahap kompetensi seseorang individu diukur menggunakan (1) pengetahuan, (2) kemahiran dan (3) mengamalkan sikap dan nilai yang dapat mewujudkan persekitaran kerja yang kompeten. Aruna (2013), menerangkan bahawa pengetahuan sedia ada, kemahiran dan juga sikap menjadi satu faktor yang paling utama untuk menentukan kompetensi seseorang individu yang menggalas tanggungjawab sebagai guru, tenaga pengajar mahupun jurulatih. Aruna et al. (2014) menerangkan bahawa seseorang individu dianggap sebagai kompeten apabila mereka dapat menggunakan pengetahuan dan kemahiran mereka dalam sesuatu bidang yang diceburi dengan jayanya dalam apa jua situasi dan persekitaran. Douban (2013), pula merangkumkan beberapa aspek yang melibatkan masalah kompetensi dalam kalangan tenaga pengajar dalam pelaksanaan sistem pendidikan 
tinggi di Malaysia. Antara aspek yang telibat dalam masalah kompetensi ini adalah kemahiran, pengetahuan dan juga tingkah laku (sikap). Menurut mereka lagi, kemahiran sebenarnya kebolehan yang kita belajar dan berulang kali digunakan apabila perlu. Semasa pengajaran dijalankan, cara kita berkomunikasi dengan pelajar dan mendengar hujah mereka, cara kita memberi contoh atau menggambarkan konsep tertentu, cara kita bertanyakan soalan, dan hampir semua yang dilakukan adalah dengan objektif untuk meningkatkan kemahiran. Terdapat beberapa kemahiran yang membentuk elemen kompetensi. Oleh itu, kemahiran adalah fokus utama pendidikan industri dan latihan. Manakala aspek pengetahuan merupakan ilmu yang digunakan atau maklumat berpengalaman. Lazimnya, ilmu yang ada disertakan dengan kemahiran. Dalam kumpulan pelatih tentunya akan terdapat perbezaan antara individu yang mempunyai ilmu berserta kemahiran dengan individu yang ada ilmu tapi tanpa kemahiran. Dari aspek tingkah laku (sikap) pula, ia merujuk kepada cara kita mengendalikan diri kita dalam pekerjaan kita apabila menjalankan tanggungjawab, tugas dan fungsi khas.

\section{Kompetensi dan Keperluan Industri}

Sementara itu, Caroline (2013), menyatakan permintaan industri adalah berasaskan kurikulum, penilaian dan pembelajaran bahanbahan yang direka dan diperuntukkan. Kompetensi seseorang diukur melalui apa yang dapat dilakukan dan dilaksana oleh seseorang individu di tempat kerja berbanding tahap pengetahuan ilmu teorinya. Selain itu, Misug (2014), dalam kajiannya menyatakan untuk menjadi seorang pembimbing di pusat latihan vokasional di Korea, guru perlu mempunyai kelayakan yang relevan dalam bidang tertentu dan menjalani kursus latihan di pusat latihan pembangunan sumber mausia (HRD) di Korea. Okoye (2015), dalam kajiannya telah menjelaskan satu lagi aspek baru yang mempengaruhi tahap kompetensi individu, yakni penilaian. Okoye dalam kajiannya pula menjelaskan bahawa penilaian adalah satu proses mengumpul bukti prestasi, yang digunakan untuk menilai tahap kompetensi pembimbing. Penilaian adalah proses mengukur tenaga pengajar berkemahiran, pengetahuan dan mempunyai kefahaman terhadap standard yang ditetapkan bagi bidang tertentu. Jika tenaga pengajar dapat memenuhi keseluruhan syarat bagi penilaian, mereka layak dianggap kompeten dalam bidang tersebut.

\section{Penilaian Kompetensi}

UNESCO-UNEVOC (2012), menyatakan penilaian berasaskan kompetensi adalah proses mengumpul bukti dan membuat penilaian terhadap tahap kompetensi seseorang individu. Hal ini, menjadi suatu kelayakan yang mengesahkan seseorang individu boleh menjalankan tugas seperti yang dikehendaki di tempat kerja seperti mana standard yang ditetapkan oleh industri (atau kelayakan yang diiktiraf melalui kursus-kursus latihan). Secara ringkasnya, penilaian dilakukan untuk membolehkan tahap kompetensi individu dinilai. Tahap kompetensi standard pembimbing boleh dijelaskan seperti dalam Rajah 1.

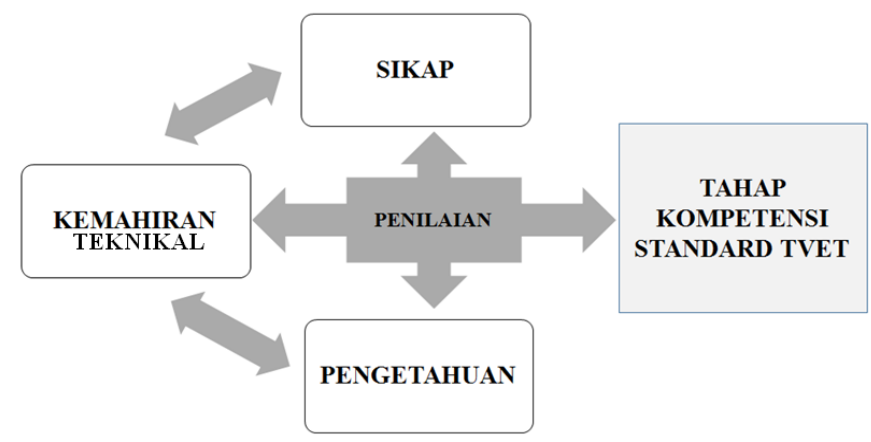

Rajah 1 Tahap Kompetensi Standard TVET

\subsection{ANALISIS SOROTAN LITERATUR}

\section{Tahap Kompetensi TVET}

Berdasarkan data terkumpul yang telah dianalisis, secara historis, induktif dan deduktif, didapati kebanyakan pengkaji berpendapat pelaksanaan program SLDN adalah memuaskan kecuali dalam aspek kompetensi pembimbing, yang mana perlu penambahbaikan. Hasil dapatan mendapati bahawa, tahap kompetensi pembimbing lazimnya, terdiri daripada tiga tahap yakni, kemahiran teknikal, pengetahuan, dan sikap pembimbing itu sendiri. Secara umumnya, untuk memastikan tahap kompetensi pembimbing, penilaian harus dilakukan. Menurut Harris et al. (1995), sebilangan soalan reflektif merujuk kepada tiga kategori (pengetahuan, kemahiran teknikal dan tingkah laku) yang mana ianya perlu jelas sebelum pelaksanaan latihan kemahiran berasaskan kompetensi dilaksanakan. Oleh yang demikian, kejayaan pelaksanaan latihan kemahiran berasaskan kompetensi adalah penting bagi mengetahui tahap kompetensi pembimbing. Penilaian memainkan peranan terbesar dan memerlukan langkah-langkah pelaksanaan yang terancang. Oleh yang demikian, Bahagian ini akan membincangkan tentang aspek pengetahuan, kemahiran teknikal, dan sikap yang yang perlu diamalkan oleh pembimbing SLDN. Di samping itu, bahagian ini juga menyentuh secara ringkas, tentang bentuk penilaian yang perlu dilaksanakan terhadap tahap kompetensi pembimbing.

Pengetahuan merupakan kemahiran asas dan kemahiran kognitif (Gray \& Herr, 1998). Pekerja yang mempunyai pengetahuan bukan sahaja dapat memikirkan semula sesuatu yang baru malah mudah mendapatkan sesuatu maklumat dan dapat mengaplikasikan semula maklumat tersebut (Rahim et al., 2007). Terdapat dua jenis latihan kemahiran pengetahuan yang disediakan oleh IKS kepada pelatih SLDN, iaitu elemen komunikasi dan elemen pengurusan maklumat. Oleh itu, untuk memastikan latihan kemahiran pengetahuan ini berjaya disampaikan, pembimbing terlebih dahulu perlu melengkapkan dirinya dengan pengetahuan. Menurut Annan et al. (2005), 
amalan komunikasi antara tenaga pengajar dan pelatih adalah mekanisme yang sangat penting untuk memastikan proses pemindahan pengetahuan, kemahiran dan kebolehan berlaku secara terancang dan memberi kesan positif terhadap sikap dan tingkah laku pelatih. Billing (2003), telah melakukan kajian berkaitan kemahiran yang diperlukan oleh pekerja dan mendapati bahawa terdapat persamaan dan persetujuan yang jelas bagi negara-negara tersebut memberikan keutamaan yang tinggi kepada kemahiran komunikasi. Menurut kajian Yahaya et al. (2004), para majikan di Malaysia hari ini memerlukan pekerja yang berpengetahuan tetapi terdapat perbezaan besar antara jangkaan majikan dengan pengetahuan para pekerja kilang kerana $80 \%$ pekerja didapati tidak mempunyai kelayakan bekerja dan satu pertiga daripada pemohon ditolak permohonannya kerana gagal dalam ujian pembacaan dan juga kemahiran menulis. Jadual 2 menunjukkan lima kemahiran pengetahuan dan akademik yang telah diselidik oleh Zirkle (1998) melalui kajian "Perceptions of Vocational Educators and Human Resource/Training and Development Professionals Regarding Skills Dimensions of School to Work Transition Programs."

Jadual 2 Pengetahuan (Sumber: Zirkle, 1998)

\begin{tabular}{|l|l|}
\hline Kemahiran pengetahuan akademik & \multicolumn{1}{|c|}{ Keterangan } \\
\hline Kemahiran membaca & Mampu untuk memahami bahan-bahan bercetak \\
\hline Kemahiran menulis & Mampu untuk mentafsir, melaksana maklumat dalam bentuk penulisan \\
\hline Kemahiran Asas matematik & Mampu untuk menambah, mendarab, menolak, dan membahagi dalam pengiraan matematik \\
\hline Kemahiran tinggi dalam matematik & Mampu untuk melakukan pengiraan menggunakan algebra, geometri dan trigonometri \\
\hline Kemahiran komunikasi secara lisan & Mampu untuk mendengar dan bercakap dengan jelas dan mudah untuk difahami. \\
\hline
\end{tabular}

SLDN juga memerlukan pembimbing yang mempunyai kemahiran teknikal yang tinggi terutamanya dalam sektor pembuatan. Hal ini kerana, dengan kemahiran yang tinggi dalam diri pembimbing, ianya dapat melahirkan pelatih yang mampu mengendalikan pengoperasian di industri yang mereka akan ceburi (Zulkifli \& Johan, 2005). Kemahiran teknikal adalah satu kemahiran yang melibatkan psikomotor dalam melakukan sesuatu pekerjaan (Hellwig, 2006). Terdapat lima elemen yang wujud antaranya ialah teknik kerja, pengurusan projek, pengurusan penyelenggaraan, kawalan kualiti dan pengurusan masalah. Hasil kajian mendapati bahawa semua item dalam penyediaan kemahiran teknikal adalah tinggi. Hasil kajian mereka juga selari dengan kajian Rosa (2000), yang menyatakan bahawa pekerja lebih mudah menguasai kemahiran teknikal yang boleh dipelajari melalui kursus dan latihan. Bagi memastikan hasrat SLDN melahirkan tenaga kerja yang dapat mengusai kemahiran teknikal ketika menjalani latihan, pembimbing adalah tonggak utama yang akan menentukan sama ada pelatihnya berjaya menguasai ataupun tidak kemahiran teknikal yang telah diajarkan. Dapatan kajian mengenai kemahiran teknikal oleh Zirkle (1998) mendapati elemen kemahiran teknikal adalah seperti yang digambarkan dalam Jadual 3.

Jadual 3 Kemahiran teknikal (sumber: Zirkle, 1998)

\begin{tabular}{|l|l|}
\hline Kemahiran teknikal/pekerjaan & \\
\hline Keselamatan dan kesihatan & Mampu mengurus diri dalam keadaan selamat di tempat kerja. \\
\hline Kemahiran penggunaan alatan utama & Mampu untuk menggunakan alatan tangan dalam kerja-kerja yang tertentu. \\
\hline Kemahiran asas operasi mesin & Mampu untuk mengendalikan peralatan mesin dalam menghasilkan produk. \\
\hline Kemahiran pembacaan ketukangan & Mampu untuk memahami panduan penulisan, panduan prosedur dan kertas kerja. \\
\hline Kemahiran tinggi operasi mesin & Mampu memasang dan mengendalikan peralatan mesin dalam menghasilkan produk \\
\hline Kemahiran melakar dan melukis & Mampu mencipta ilustrasi yang berkaiatan dengan kerja-kerja yang dihasilkan. \\
\hline Kemahiran matematik perdagangan yang khusus & Mampu mengendalikan masalah perniagaan berkaiatan operasi matematik. \\
\hline Kemahiran jaminan keselamatan & Mampu untuk bertanggungjawab terhadap setiap produk yang dihasilkan. \\
\hline Kemahiran asas komputer & $\begin{array}{l}\text { Mampu untuk melakukan kerja dalam *DOS, Window atau pekerjaan yang berkaitan } \\
\text { Kemahiran tinggi komputer }\end{array}$ \\
\hline *Perisian yang terdapat semasa kajian ini dilakukan dan perlukan dikemaskini dan disesuaikan dengan teknologi semasa.
\end{tabular}

Sementara itu, keperluan pembimbing mengamalkan sikap dan etika kerja amatlah dituntut agar SLDN mampu melahirkan graduan yang tinggi jati diri. Atikah (2015), menjelaskan pembimbing dikatakan tidak kompeten sekiranya mereka tidak mempunyai kemahiran dan sikap yang terpuji dan pengetahuan mendalam bagi kemahiran yang diperlukan. Dari segi sikap, memiliki sikap yang negatif juga menjadikan pembimbing tidak kompeten, misalnya pembimbing mempunyai sikap negatif yang sememangnya tidak mengambil berat tentang tanggungjawab untuk membimbing pelatih. Pembimbing yang tidak bertanggungjawab pada kebiasaannya bersikap sambil lewa tanpa memikirkan kemungkinan akibat daripada kelalaian mereka dalam membimbing. Rajah 2 menunjukkan peranan pembimbing semasa proses Pengajaran dan Pembelajaran dalam pembetukan nilai pelajar (Ahmad, 2005).

Selain itu, pembimbing juga perlu bertindak sebagai ketua atau pemimpin yang dapat memantau kemajuan pelatih dan dapat merangsang pelatih untuk berfikir dalam pengajaran supaya dapat memimpin dengan berkesan dan mampu untuk menjadi model ikutan kepada pelatih. Pembimbing juga perlu mempunyai sifat-sifat positif seperti memberi sokongan kepada pelatih, sentiasa memberikan sepenuh perhatian kepada pelatih, menjalinkan komunikasi tentang pelajaran dengan pelatih, memupuk sikap positif dalam diri pelatih dan menilai amalan pelatih. Strategi bimbingan iaitu fikir, padankan dan kongsi juga perlu diterapkan dalam diri setiap pembimbing. Pembimbing juga adalah pemberi sokongan yang mewujudkan hubungan, perkongsian, tunjuk ajar dan kawan pada masa kritikal. Menurut Maria \& Alina (2013), pembimbing harus mempunyai kemahiran dalam pelaksanaan, komunikasi, kebolehan untuk menarik perhatian pelatih, menjaga kepentingan pelatih, keupayaan untuk membezakan aktiviti yang diperlukan oleh pelatih, kemahiran interpersonal dan kemahiran pengurusan. 




Rajah 2 Peranan pembimbing dalam pembentukan nilai (Sumber: Ahmad, 2005)

\section{Penilaian Tahap Kompetensi TVET}

Dalam pelaksanaan penilaian berasaskan Kompetensi, ia bukan sahaja penting untuk memahami dan mengaplikasikan prosedur teknikal, tetapi juga penting untuk mengetahuai beberapa prinsip yang lain. Menurut ANTA (2002), terdapat empat prinsip iaitu, kesahan, kebolehpercayaan, fleksibiliti dan keadilan merupakan ciri-ciri penting dalam penilaian yang baik. Kesahan memerlukan seseorang penilai membenarkan atau mengiktiraf apa yang telah dinilai. Kebolehpercayaan memerlukan kaedah dan prosedur yang konsisten bagi mengukur pencapaian pelajar yang berbeza dari semasa ke semasa. Keadilan diberikan apabila penilaian adalah saksama, mudah, telus dan sama rata. fleksibiliti memerlukan pelbagai kaedah penilaian, merujuk kepada pelbagai mod penghantaran, keperluan dan sudut pembelajaran yang dikehendaki. Prinsip-prinsip ini dinyatakan dengan lebih terperinci dalam Jadual 4.

Jadual 4 Prinsip-prinsip dalam penilaian (sumber: Baker et al., 1993)

Kesahan

Penilaian akan merangkumi pelbagai kemahiran dan pengetahuan yang mencukupi untuk menunjukkan kecekapan.

Penilaian kecekapan perlu menjadi satu proses yang mengintegrasikan pengetahuan dan kemahiran secara praktikal.

Semasa penilaian, dalam menentukan kecekapan, ia mestilah mengambil kira tentang penilaian yang mana ia mestilah boleh dilakukan di mana sahaja dibuat melalui bukti yang direkod, dan dalam pelbagai situasi.

Kebolehpercayaan

Amalan penilaian perlu dipantau dan dikaji semula untuk memastikan keseragaman dalam pengumpulan dan tafsiran bukti.

Penilai mesti cekap dari segi standard penilaian kecekapan kebangsaan.

Fleksibiliti

Penilaian hendaklah meliputi keseluruhan komponen tugas latihan.

Prosedur Penilaian seharusnya mengadakan pengiktirafan bagi pengenalan kecekapan tidak kira bagaimana, di mana atau bila mereka perolehi.

Prosedur Penilaian hendaklah dimaklumkan kerana ia boleh dijadikan sebagai panduan mencapai kompetensi standard.

Amalan Penilaian perlu dipantau dan dikaji semula untuk keseragaman dalam pengumpulan dan tafsiran bukti.

Penilai mesti cekap dari segi standard penilaian kecekapan kebangsaan.

Keadilan

Amalan penilaian dan kaedah yang digunakan mesti saksama kepada semua yang dinilai.

Prosedur penilaian dan kriteria untuk menilai prestasi mesti diperjelaskan.

Perlu ada penyertaan dalam pentaksiran. Penilaian memerlukan persetujuan penilai dan yang hendak dinilai sebelum boleh melakukannya.

Peluang perlu diberikan kepada yang sedang dinilai dan membuat penilaian semula jika diperlukan.

\section{Bentuk-Bentuk Pelaksanaan Penilaian}

Seseorang individu dianggap sebagai kompeten apabila mereka dapat menggunakan pengetahuan dan kemahiran untuk melakukan sesuatu kerja dengan jayanya dalam pelbagai situasi dan persekitaran, mengikut standard prestasi yang diperlukan di tempat kerja (BMZ, 2011). Penilaian terhadap kompetensi adalah proses mengumpul bukti dan membuat pengesahan bahawa tahap kompeten indivivdu telah dicapai. Dengan adanya penilaian, barulah kompetensi pembimbing SLDN dapat dikenal pasti sesuai dengan objektif pelaksanaan SLDN yakni melahirkan tenaga kerja mahir. Penilaian terhadap kompetensi yang dilaksanakan sebenarnya berdasarkan kepada standard yang dikehendaki oleh pusat latihan itu sendiri. Bukti penilaian, adalah maklumat yang dikumpul, apabila dipadankan dengan tahap penguasaan atau kecekapan seseorang. Bukti penilaian boleh diambil atau direkod dalam pelbagai bentuk dan diperoleh daripada berbagai sumber. Bentuk-bentuk penilaian boleh dilaksanakan secara langsung, tidak langsung, atau penilaian tambahan, seperti yang ditunjukkan dalam Rajah 3. 


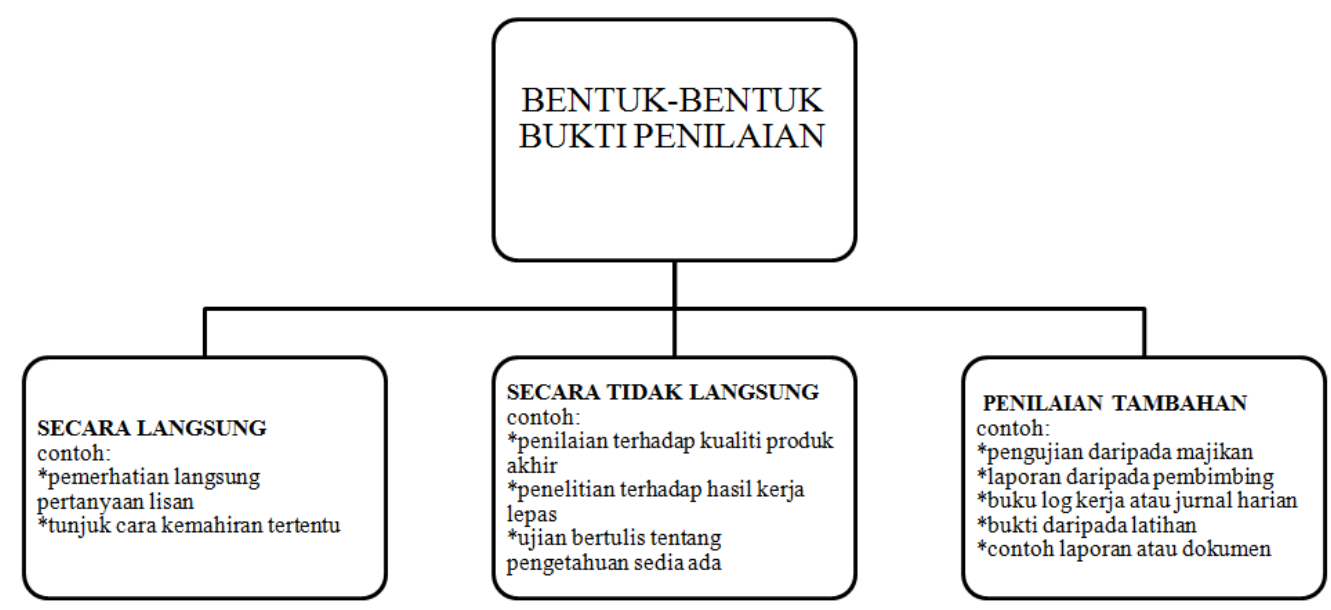

Rajah 3 bentuk bukti yang boleh dikumpul melalui penilaian (Sumber: BMZ, 2011)

Terdapat beberapa masalah dalam aspek penilaian yang timbul di dalam dan luar negara. Menurut Ridvan et al. (2012), majikan industri terlalu sibuk untuk mengekalkan nama syarikatnya dan tidak mempunyai sumber, masa dan kecenderungan untuk melatih pelatih. Secara ringkasnya, bagi mengelakkan daripada kehilangan kompetensi dalam diri pembimbing, penilaian tahap kompetensi pembimbing perlulah dilakukan dari masa ke semasa oleh setiap majikan. Penilaian adalah proses mengukur tenaga pengajar berkemahiran, pengetahuan dan mempunyai kefahaman terhadap standard yang ditetapkan bagi bidang tertentu. Jika tenaga pengajar dapat memenuhi keseluruhan syarat bagi penilaian, mereka layak dianggap kompeten dalam bidang tersebut yakni disebut sebagai mencapai tahap kompetensi standard (Okoye, 2015). Kerangka konseptual kajian membentuk pembimbing berkesan dalam SLDN boleh dijelaskan seperti dalam Rajah 4.

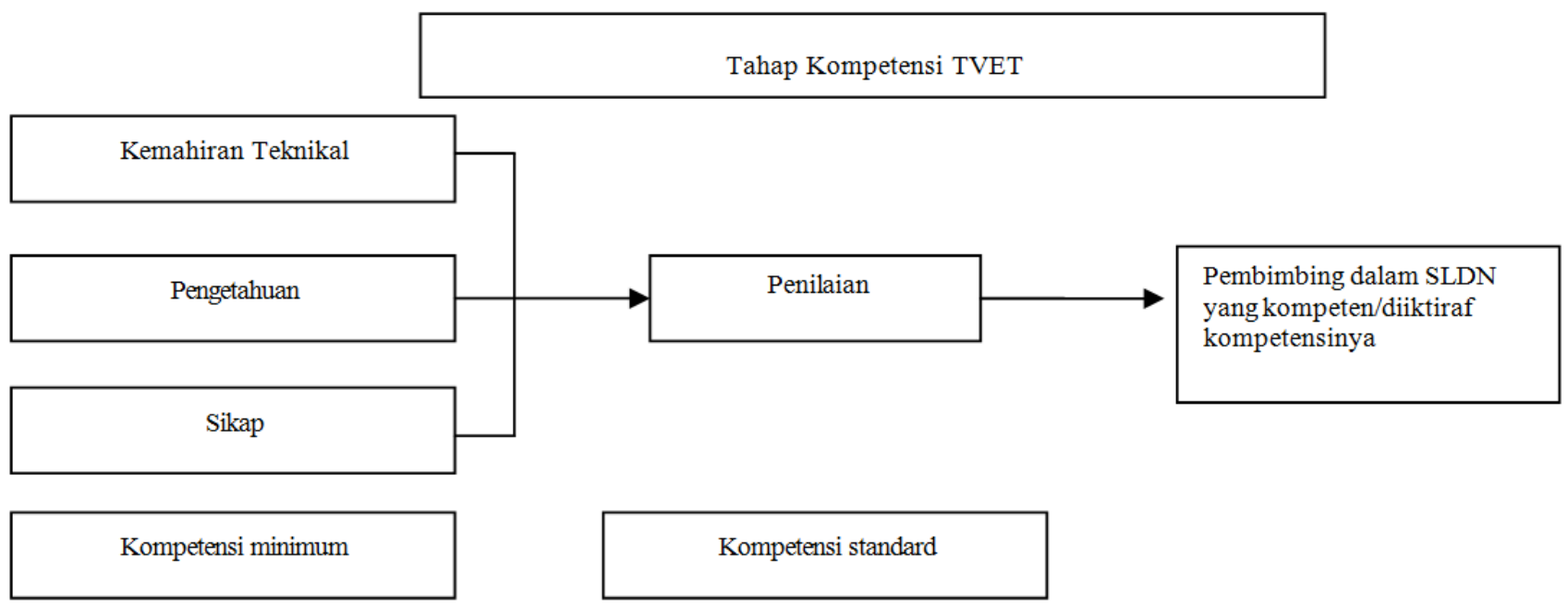

Rajah 4 Kerangka konseptual kajian membentuk pembimbing berkesan dalam SLDN

Kerangka konseptual ini telah digunakan untuk membantu menjelaskan tahap kompetensi yang perlu dimiliki oleh pembimbing SLDN dari segi pengetahuan, kemahiran, dan sikap serta bagaimana tahap kompetensi minimum menjadi tahap kompetensi standard melalui proses penilaian.

\subsection{KESIMPULAN}

Berdasarkan perbincangan sorotan literatur, jelas menunjukkan bahawa tahap kompetensi pembimbing memainkan peranan penting dalam bidang Pendidikan Teknikal dan Vokasional (TVET). Hal ini bagi memastikan pelatih mampu memenuhi kehendak industri seiring dengan kemajuan teknologi kini. Keberhasilan pelaksanaan SLDN adalah bergantung kepada tahap kompetensi pembimbing yang ditonjolkan dalam menggalas tugas sebagai tenaga pengajar. Proses perpindahan ilmu yang berkesan adalah bergantung kepada kompentensi pembimbing dalam membimbing para pelatih. Keberkesanan ilmu dan kemahiran yang disampaikan mampu memotivasikan para pelatih sekaligus mendorong para pelatih mengaplikasikanya dalam industri. Kebanyakan pengkaji b ersetuju bahawa kompetensi 
adalah kayu ukur kepada kualiti kerja pelatih. Hal ini kerana pembimbing bertindak sebagai idola dan panduan bagi para pelatihnya. Sememangnya kompetensi pembimbing adalah berdasarkan pengetahuan, kemahiran, sosial dan pengamalan etika kerja yang baik.

Walaupun begitu, kompetensi bukanlah dianggap setaraf dengan peringkat mahir atau pakar. Hal ini kerana, kompetensi tidak memerlukan masa yang terlalu panjang bagi mencapainya, berbeza dengan mahir atau pakar yang biasanya mengambil masa bertahuntahun untuk mencapainya. Namun, dengan adanya penilaian berasaskan kompetensi, tahap kompetensi pembimbing dapat dinilai dari semasa ke semasa (bagi mengumpul bukti kompetensi pembimbing). Penilaian sangat penting dalam memastikan kompetensi pembimbing sentiasa berada dalam keadaan yang konsisten pada setiap masa; yang mana pembimbing dapat mengaplikasikan semua kompetensi yang sedia ada (minimum) kepada kompetensi standard bagi mengesahkan kelayakan mereka mengajar dalam bidang tertentu. Penilaian berasaskan kompetensi ini lama kelamaan mampu membantu pembimbing mencapai tahap mahir atau pakar dalam bidang yang diajar pada masa hadapan.

Rujukan

Caroline, A. A. (2013). Competency Based Training: Quality Delivery For Technical And Vocational Education and Training (TVET) Institutions. Journal of Educational Research International, 2(2), 2307-3721.

Hasmori, A. A., et al. (2011). Sistem Latihan Kemahiran Dua Hala di Malaysia: Satu Perbandingan Dengan Negara Jerman. Journal of Edupress, 1(1), 214-222. Dharma, A. 2003. Manajemen Supervisi. Raja Grafindo Persada: Jakarta.

Ahmad, A. L. (2005). Persepsi Guru dan Pelajar Terhadap Perlakuan Buli Di Kalangan Pelajar Sekolah Menengah Daerah Batu Pahat. Tesis Sarjana Psikologi Pendidikan: Universiti Teknologi Malaysia.

Mahazani, A. (2015). Developing the Knowledge-Based Human Resources that Support the Implementation of the National Dual Training System (NDTS): Evaluation of TVET Teacher's Competency at Mara Training Institutions. Universiti Tun Hussein Onn Malaysia. Tesis Ph.D.

Ridvan, A., et al. (2012). A comparative study: A challenges and opportunities for European Union Dual Vocational training Systems. Journal of cooperative education and internship, 47(1), 4-17.

Australian National Training Authority (ANTA). (2002). A Licence to Skill, Brisbane. Retrieved from: http://catalogue.nla.gov.au/Record/2203592

Azlan. (2011). Boundary issues in social work: Managing dual relationships. Social Work, 48, 121- 133.

Yahya, B. (2004). Integrasi Kemahiran "Employability" dalam Program Pendidikan Teknik dan Vokasional Pertanian dan Industri di Malaysia. Universiti Teknologi Malaysia: Tesis Ph.D.

Zirkle, C. (1998). Perceptions of Vocational Educators and Human Resource Training and Development and Professionals Regarding on Skills Dimensions of School to Work Transition Programs. Journal of Education and Training. 15(1), 45-60.

Billing, D. (2003). Generic Cognitive Abilities in Higher Education : An International Analysis of Skills Sought by Stakeholders. Journal of Comparative and International Education. 33(3), 335-350.

Euler, D., et al. (2013). Germany's Dual Vocational Training System: A Model For Other Countries? Bertelsmann Stiftung. Retrieved from: www.bertelsmannstiftung.

Baker, E. L., et al. (1993). Policy And Validity Prospects For Performance-Based Assessment, in: American Psychologist, no.48, pp.1210-1218.

Federal Ministry for Economic Cooperation and Development, BMZ (2011). Through Competence-Based to Employment Oriented Education and Training. Germany: Ministry for Economic Cooperation and Development. Retrieved from: https://www.giz.de/akademie/de/downloads/EmploymentOriented_Education_and_Training.pdf.

Annan, I., et al. (2005). Amalan Komunikasi dalam Program Mentoring : Pemindahan Pengetahuan, Kemahiran dan Kebolehan Memainkan Peranan Bersyarat dalam Organisasi. Jurnal Pendidikan. Jilid 5. Halaman 46-49.

Aruna, I. (2013). The Development of a New Malaysian Skills Qualification Framework (MSQF) in the Context of National Dual Training System (NDTS). Universiti Tun Hussein Onn Malaysia. Tesis Ph.D.

Aruna, I., et al. (2014). Implementation of National Dual Training System (NTDS) on Producing K-Workers in Malaysia. Journal of Science, Mathematics and Technology, 1(2), 22-29.

Daud, I. (2003). Mengenalpasti Masalah-masalah Dalam Melaksanakan Standard ISO 9000. Tesis Sarjana. Bangi : UKM Innovation and Business Skills Australia, IBSA (2012). Competency Based Assessment. Australia. Retrieved from: https://www.ibsa.org.au/tae10-resources.

International Center for Technical and Vocational Education and Training, UNESCO-UNEVOC (2012). Competence Standards for Technical and Vocational Education and Training TVET. Bonn: Germany. Retrieved from: http://www.unevoc.unesco.org/e forum/CompetenceStandardsforTVET.pdf.

Jabatan Penerangan Malaysia, JPM (2001). Eighth Malaysia Plan 2001-2005. Putrajaya: Economic Planning Unit (EPU), Prime Minister's Department. Retrieved from: http://www.pmo.gov.my/dokumenattached/RMK/RM8.pdf.

Jabatan Penerangan Malaysia, JPM (2011). The Tenth Malaysia Plan, 2011-2015. Putrajaya: Economic Planning Unit (EPU), Prime Minister's Department. Retrieved from: http://www.pmo.gov.my/dokumenattached/RMK/RMK10_Mds.pdf.

Atikah, J. (2015). Kompetensi Pembimbing Syarikat Bertauliah Sistem Latihan Dual Nasional (SLDN). Universiti Tun Hussein Onn Malaysia.

Misug, J. (2014). Transferable Skills Education in Technical and Vocational Education and Training (TVET) in the Republic of Korea. Journal for Technical and Vocational Education and Traning in Asia, 3, 1-17.

Gray, K. C., \& Herr, E. L. (1998). Workforce Education the Basics. Needham: Allyn and Bacon Publishing.

Okoye Michael, K. R. E. \& Ofonmbuk, I. (2015). Enhancing Technical and Vocational Education and Training (TVET) in Nigeria for Sustainable Development: Competency-Based Training (CBT) Approach. Journal Education and Practice, 6(29), 1-4.

Deros, M., et al. (2012). An Employer Survey on Industrial Sector Involvement in Malaysian National Dual Training System. Asian Social Science, 8(16), 232-239.

Alwi, N. (2006). Knowledge Acquisition, Transfer and Utilization in the Malaysian Aviation Industry. Unpublished doctoral dissertation, School of Graduate studies, Universiti Putra Malaysia.

Ahmad, O., et al. (2011). The Emerging Roles of Coaches in the Malaysian Dual Training System. Journal of Education Studies, 4 (1).

Maria-Monica, P. M. \& Alina, M. C. (2013). Students-teacher perspectives on the qualities of mentor-teachers. Precedia-Social and Behavioral Sciences, 116, 35593563.

Bekri, R. (2015). E-Portfolio Indicator For Competency Assessment And Virtual Learning in Malays ia Skills Certification. Journal for Technical and Vocational Education and Traning in Asia, 4, 1-14.

Douban, R., \& Wong.T. F. Competence Based Education Framework: Implications for Higher Education Process in Malaysia. Journal of Education,1-7.

Mohd, S. \& Kamarul, A. (2013). Pelaksanaan Program Kerjasama Institusi Industri di Politeknik Merlimau Melaka. Tesis Master. 